\title{
TALES FROM THE CONGO RIVER: CATCHING MAMI WATA
}

[Received March 28th 2021; accepted April 28th 2021 - DOI: 10.21463/shima.125]

\section{Lesley Braun}

<lesnbraun@gmail.com> University of Basel

\begin{abstract}
Digital culture produces new dislocations, proximities and anxieties. Central here is "meme" culture, whose fluid movement morphs in transmission, drawing on older cultural symbols to create a feedback loop. One folkloric aquatic figure from the African continent and its diasporas, known as Mami Wata, exemplifies this memetic force that is carried over into the digital realm. Mami Wata is dualistic: human and water creature, beautiful and terrifying, pre-colonial and modern. She is fluid, not bound by traditionally grounded mobilities, and her origins are mysterious. Further, she thrives through time and place via rumour and her message and meaning are in constant flux. She is also a symbol of temptation, which carries with it anxiety. Mami Wata is said to haunt the banks of the mighty Congo River and its tributaries, waiting for new victims, thus serving as a cautionary tale, warning people of these potential fluvial supernatural encounters. As we will see, in the face of digitalisation and globalisation, contemporary memes and viral videos of Mami Wata give us a screen to view our own anxious projections. And yet she also reveals the possibility of encounter: an other who shows us another way. Drawing from extensive ethnographic fieldwork in Kinshasa, capital of the Democratic Republic of Congo (DRC) beginning in 2012, what emerges are parallels between Mami Wata and virality, and how they represent both an attitude and an ambiance in Kinshasa. What is more, we find that Mami Wata shows us a structure by which rumours, memes and in-group culture endure through time, not despite, but thanks to their mysterious origins and fluid meanings.
\end{abstract}

KEYWORDS: Mami Wata; Democratic Republic of Congo; Rumour; Visual culture; digital technology

\section{Introduction}

Central Africa, particularly the region now known as the Democratic Republic of Congo (DRC), has attracted the attention of explorers and scholars who have been long attempting to navigate these literal and metaphoric distant waters. The DRC is also a source of fascination for the wider public eager to consume a projected exoticism, which is then reflected back to them. While the Belgian colonial enterprise no longer officially operates in the DRC, researchers continue to risk carrying over those colonial attitudes by exoticising people and places in all manner of representation. Central to this paper is Mami Wata, a half-human and half-aquatic water deity who features prominently in many African pre-colonial oral histories, as well as in colonial and postcolonial visual cultures. Mami Wata can be seen as an embodiment of the tension across the social sciences, particularly within the discipline of anthropology, regarding the "othering" and "saming" of people. This siren is both the recognition of ourselves in our projections, as well as the source of uncertainty as to our motivations and curiosities for studying certain things we

Shima <www.shimajournal.org $>$ ISSN: 1834-6057 


\section{Braun: Catching Mama Wata}

deem other. In many ways, Mami Wata serves as a facilitator of encounter between the familiar and the strange.

While this paper focuses on a seemingly exotic fantastical creature, it seeks to show an amalgam of circulating influences that occur from encounters between people and things. What is more, it explores the very contemporary medium to which these encounters are migrating: the digital domain, especially its iterative and diffusionary logic of memes. As such, this paper stands in contrast to Henry John Drewal's prolific work about Mami Wata, in which he highlights the archetypal qualities associated with this feminine water spirit and the way it is interpreted in other cultural contexts in search of similarities $(2008 ; 2013)$. Rather, it will focus on the potency of traveling images that are now accelerated in the digital world. Digital culture produces new dislocations, proximities and anxieties. Central here is "meme" culture, whose fluid movement morphs in transmission, drawing on older cultural symbols to create a feedback loop. Mami Wata, a folkloric figure from the African continent and its diasporas, exemplifies this memetic force that is carried over into the digital realm.

Kinshasa, capital city of the DRC, is situated in the Pool Malebo region where the lower part of the Congo River widens, creating a lake-like formation and producing confluences upstream. One seminal book entitled Kinshasa: Tales of the Invisible City by Filip De Boeck and Marie-Francoise Plissart (2004) explores the various ways in which infrastructure can be thought of as more than the built environment-networks of people, even people's own bodies produce supportive and communicative structures. Rumours are orally transmitted through networks of people, with what is idiomatically referred to as radio trottoir, or "pavement radio". As we will see, radio trottoir is now also comprised of virtual online networks. Like many big or capital cities, Kinshasa has for a long time attracted people from all over the country with the promise of new and better ways of life. There is a sense in which the city bewitches people aspiring to become urban dwellers, as Lye Yoka, a local intellectual and prolific writer, describes:

Kinshasa is at once woman, river, language. Kinshasa the woman. Almost all African poets who have flirted with the city realized that she was a kind of "Mami Wata" capable of the worst and the best. A tentacle monster, and yet a real lure for the majority of young people confined to misery in rural areas, Kinshasa continues to make people dream... A proud city without arrogance, which charms without accosting, which gives of itself without giving itself up. But when she does finally show her real self-in drunkenness, music, beer, folly—she bewitches, irremediably, the impatient suitor. (1999: 95).

Yoka emphasised several things that will recur in this article: the idea of dual-nature (the "worst and the best"), the temptation for new and exciting things ("a real lure"), and finally, a bewitching/revealing sense of encounter. This also speaks to the ambiance in Kinshasa that is ripe for cultural dissemination, and suffused with a proximity-anxiety that only gets amplified in the digital sphere.

Drawing from extensive ethnographic fieldwork in Kinshasa, capital of the Democratic Republic of Congo (DRC) beginning in 2012, what emerges are parallels between Mami Wata and virality, and how they represent both an attitude and an ambiance in Kinshasa. What is more, we find that Mami Wata shows us a structure by which rumours, memes and in-group culture endure through time, not despite, but thanks to their mysterious origins and fluid meanings.

Shima Volume 15 Number 22021 


\section{Braun: Catching Mama Wata}
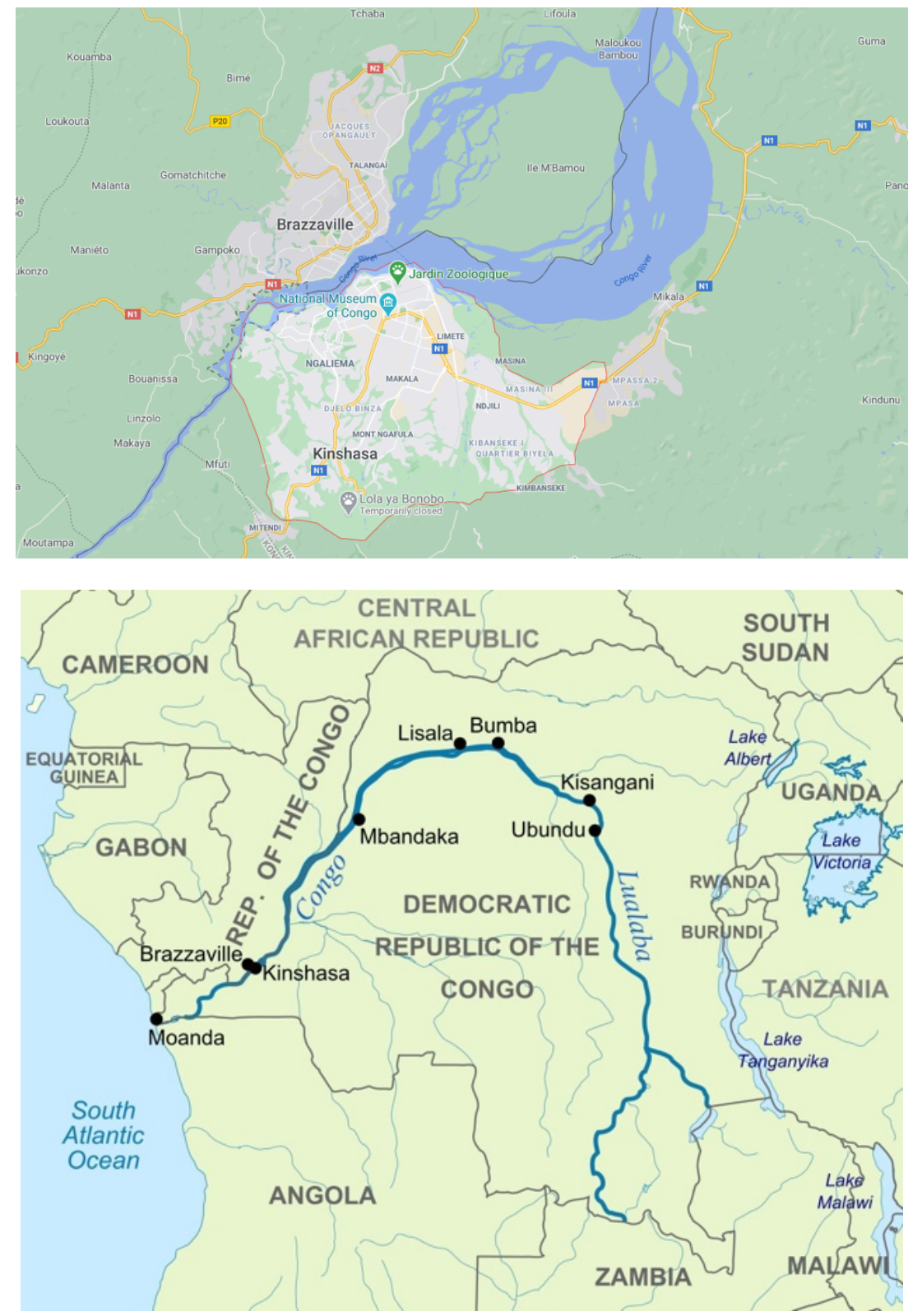

Figures 1 and 2 - Maps of Pool Malebo where Kinshasa, capital of the Democratic Republic of Congo is situated (Google Maps and Wikimedia Commons).

This short article draws from these impressions and conversations to offer a fragment of one urban popular expression that seems to continually be iterated upon, reflecting social change and the anxieties that often come with it. 


\section{Braun: Catching Mama Wata}

\section{The tale of Mami Wata}

Mami Wata is the Mother of Water. Tales of Mami Wata have been iterated in stories, song, poetry, and painting. She also makes appearances in daily parlance. For instance, when a man walks down the street in downtown Kinshasa and spots a lovely young woman he might say, 'She could be Mami Wata.' Her visual depiction is similar to that of a mermaid, except instead of a fin, she sometimes is depicted together with a longer serpent's tail, echoing a Biblical Eve-serpent fusion (Figure 1). Here are many of the main elements: femininity, temptation, both sexual and material, and doom.

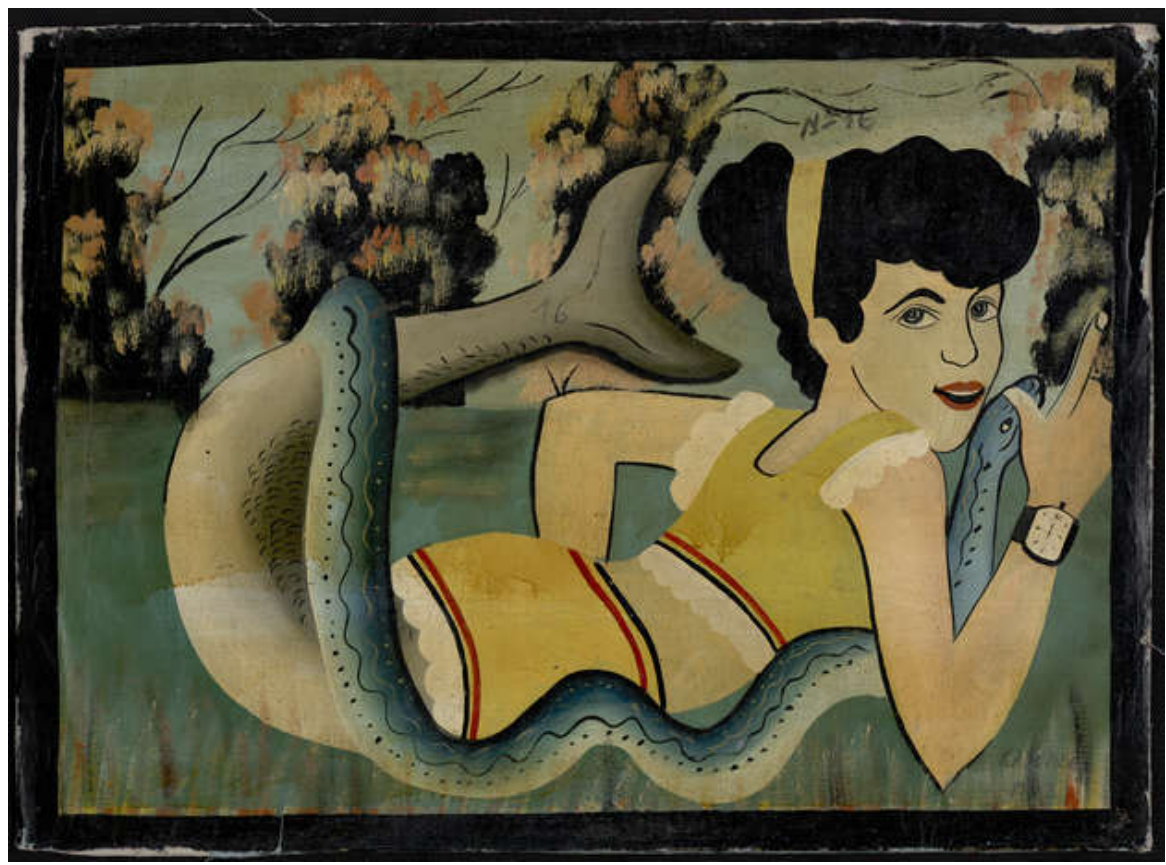

Figure 3 - A painting from c 1950 of Mami Wata and a snake coiled around her. (HO.2013.57.1908, collection RMCA Tervuren; photo RMCA Tervuren Kayembe F., Mami Wata. All rights reserved.)

Water is Mami Wata's milieu, pointing to the ways in which fluid mobility is polydirectional; there are no set paths one must follow, either in swimming or along semantic chains. She is never situated statically; rather, she exists in a continuous state of passage, swimming between a broad network of people and places: word-of-mouth, gossip, rumours. This is how the story of Mami Wata spread, like water. Further, the mirror-like surface of the water reflects how we project ourselves into the stories we transmit, reservoirs for the justifications for desire and fear. Visual representations of Mami Wata also depict her gazing at herself in a handheld mirror: a luxury object of foreign import from the colonial era (Figures 2 and 3), but also a common featured object in depictions of mermaids in the west. The mirror is the symbol of mimesis: reflection and projection. But the mimetic force easily morphs into a memetic force. Starting from reflection and projection we often end up in reproduction and circulation. And visual imagery, from the painting to the photograph to the digital image, is the ideal cultural meta-content with 


\section{Braun: Catching Mama Wata}

which to trace the trajectory from mimesis to memetics. As we will circle back to later, visual representations of Mami Wata and her mirror exemplifies this trajectory and all the encounters, dislocations and anxieties it produces.

The temptation of vanity is apparent in these images as well as the sly look of misrecognition. Mami Wata is evoking interpretations of projected selfhoods bound up in foreign influence. All life begins in water, as the woman carries water in her womb for the babe. Being a water figure further enhances Mami Wata's feminine force: sometimes as seductress, but other times in a more maternal manner. She can be a protector, especially in regards to her association with the Congo River: a spawn of Mother Nature.

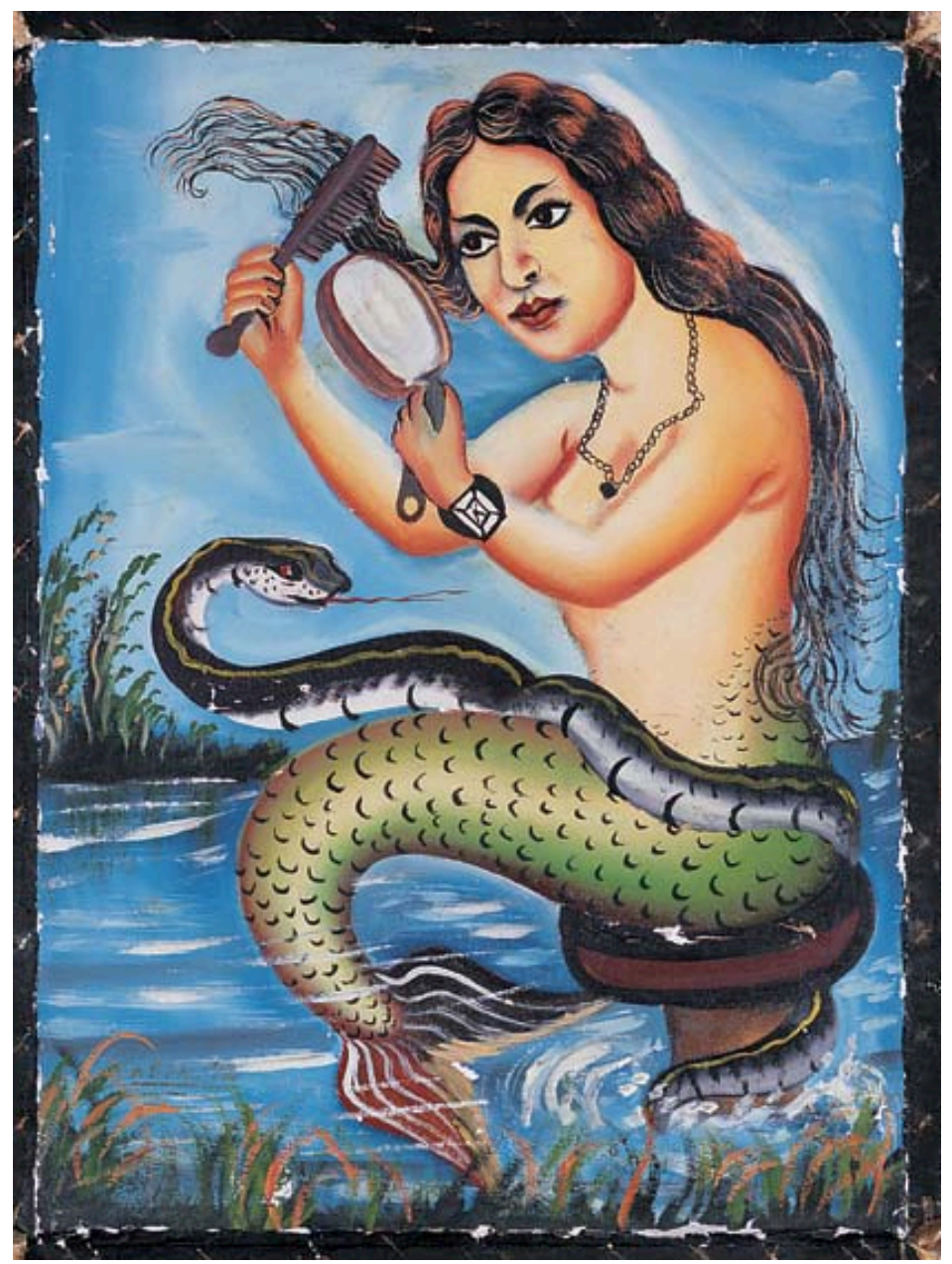

Figure. 4 - 'La sirène'(Mamba Muntu) se peigne.' (HO.2013.57.1966, collection RMCA Tervuren; photo RMCA Tervuren Abdala. All rights reserved.)

\footnotetext{
${ }^{1}$ Mami Wata has also been deployed as a symbol for environmental protection in West Africa, specifically ocean management, as the multilateral Mami Wata Project attests to. For more about this see: http://mamiwataproject.org/
} 


\section{Braun: Catching Mama Wata}

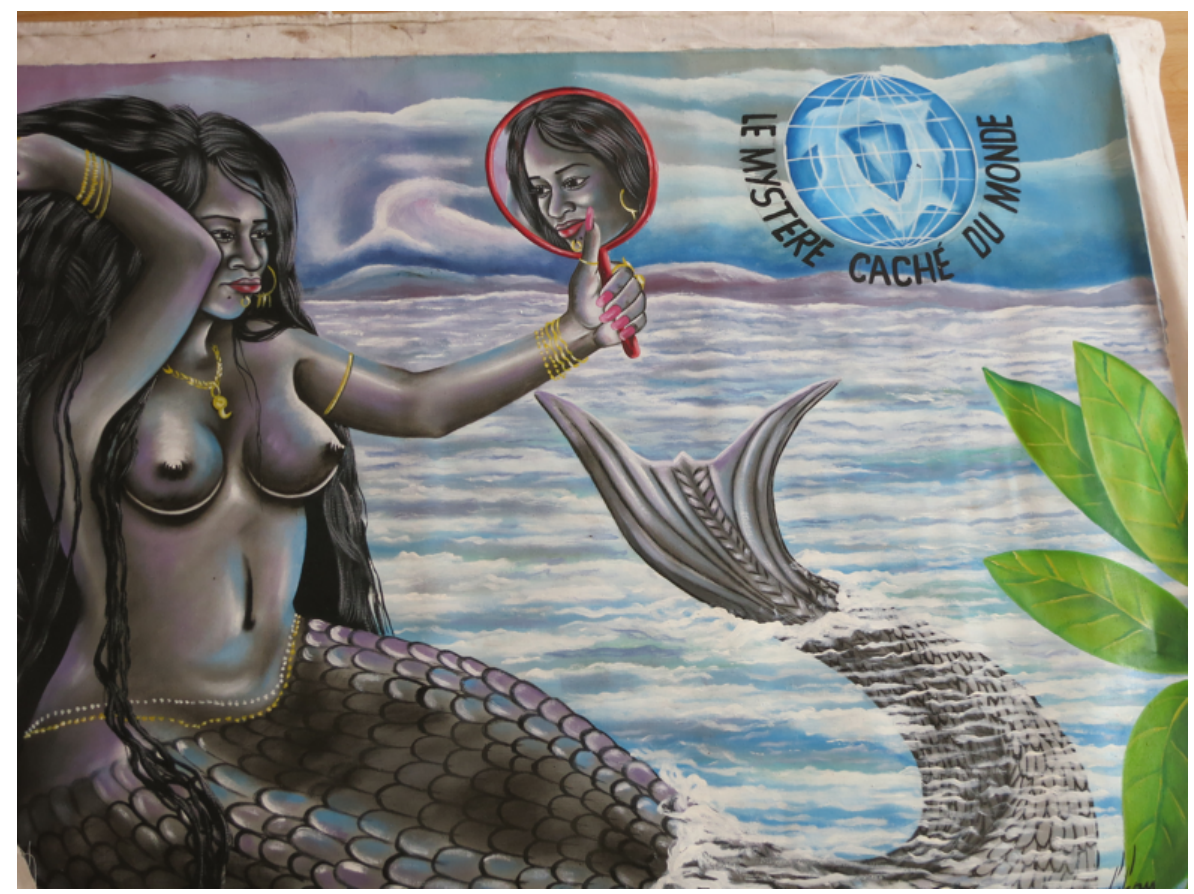

Figure 5 - 'The hidden mystery of the world,' photo of painting 2010 (unknown artist) from author's own collection.

Like the Congo River, she flows through many parts of Africa but does not adhere to the same form everywhere. The nature of her ambiguity and otherness results in diverse interpretations, and reflects a plurality of belief systems. In West Africa, loyal devotees publicly worship her as a deity and construct elaborate shrines in her honor. Yet in the Kinshasa, Mami Wata is thought to be a menacing siren who lures men with the promise of riches in exchange for their loyalty. Mysterious wealth accumulation becomes fodder for speculation and wealth men can be suspected of making pacts with Mami Wata, eliciting refrains like: "azalaka na mwasi ya Mami Wata, mbongo naye eza mystique" (he has a Mami Wata, his money is mystical). Here, perceived suspicious and dubious sources of wealth are considered immoral because they are linked to occult forces that have been harnessed in its acquisition. Mami Wata is also linked perceptions of women being wily, opportunists, seeking to enrich themselves on men's resources.

\section{On temptation and anxiety}

Feminised aquatic creatures such as mermaids are often projections of male anxiety. They are conceived of in a dualistic manner-at once a source of life and death, producing an ambivalence about their presence. Further, watery realms are closely linked to the amniotic fluid in which life emerges, and therefore by extension, to feminine power (Fabian 1996; Touya 2003). They are also the scene of darkness and drowning. Mami Wata is the irresistible temptress both for her beauty alone, but also by offering men material wealth and success in exchange for loyalty or a sacrifice. Sometimes this sacrifice comes in the form of a man's loved one- a death in the family can carry with it suspicions of foul play. 
Other times it is a man's own fertility or virility she robs (here are connotations of virality, which we take up later). As stated earlier, she is not publicly worshiped in the Kinshasa. The name Mami Wata is even used there as a pejorative for sex workers, again linking sexual temptation with the dangers of separating a man from the fruits of his labor. Having no legs is both an obstacle to the sexual impulse, and a mystifying force induced by the uncanny. But Mami Wata is said to be able to conceal her tail and expose her legs at any given moment. She is a symbol of hybridity, but can also be a harbinger of Otherness.

It is a fluid passage from anxiety over the female to other forms of anxiety. Mami Wata bears the imprint of the colonial encounter and modernisation. For example, the 1950s brought with them intense urbanisation projects in Léopoldville, now known as Kinshasa (Biaya, 1996; Gondola, 1997). This also included a flooding in of new import goods, and with them, commodity-advertising lifestyle culture modeled after Europe. During this time, Mami Wata paintings became popular, and often featured the siren donning a watch, which during the colonial period was a potent symbol of aspirational luxury (Figures 3 and 4). Clock-time is also symbolic of the rigid organisation of daily life so necessary to capitalist modes of production, which also transforms people and society. For many people then, she became a figure of seduction and ruin, as well as a warning against a culture of immediate gratification of manufactured desires, and the societal upheaval that capitalism brings.

\section{A tale of cultural diffusionism}

Before we turn to a discussion about the relationship between viral media and Mami Wata, I would like to offer a brief sketch of one thread in early 2oth Century ethnological thought as it relates to encounter. As we will see, this ties into memetic diffusion and virality.

Diffusionist theories trace modes of encounter through the spread of cultural traits or ideas across geographic space. These are sometimes violent, emerging from conflict and colonialism, or otherwise through trade and migration. Indeed, the influence between groups is not one-way or static. Rather, encounter entails mutual and continual change of cultural ideas and practices. Franz Boas, a pioneer in the discipline of American anthropology and early proponent of diffusionist theory, challenged prevailing biological evolutionary theories of culture through an analysis of detailed empirical evidence (1904). Rather than being inherited genetically, scholars proposed that culture is transmitted and acquired through learning, borrowing and mimicking in an endless process (Kroeber, 1923; Murdock, 1940). Boas sought to understand culture in terms of processes of diffusion and modification. This approach would inform scholarship for years to come, particularly with regards to theories of relationality.

In Édouard Glissant's seminal postcolonial text, The Poetics of Relation, he articulates that: "Relations of multiplicity or contagion exist wherever mixtures explode momentary flashes of creation, especially in the languages of young people" (1997 [1928]: 105). Here we have the importance of "mixtures" and "momentary" encounters instead of dominant and fixed. Glissant emphasises: "The tale of errantry is a tale of Relation" (ibid: 18). Wandering, encountering, and remaining open to how others might change you: this is how the circulation of people, goods, and ideas functions. This errant quality points to how meanings must wander and occasionally be deformed by relations with others. It's not just the new things that have influence, but the places they come from do too. Writing about the ways in which Indian material culture impacted visual representations of Mami Wata 


\section{Braun: Catching Mama Wata}

in Africa in the 1940 s and 1950s, Henry Drewal states: "[t]he popularity of the snake charmer lithograph and the presence of Indian merchants (and films) in West Africa led to a growing fascination with Indian prints of Hindu gods and goddesses" (2008: 71). It follows that Mami Wata is often portrayed in paintings and murals as fair-skinned with long flowing black hair - sometimes with an Indian-style bhindi. Echoing Glissant's writings about relationality, this siren represents changing perceptions of 'otherness' and the 'exotic', where the foreign is continuously interpreted. As Kinshasa's citizens try to understand themselves in images of Mami Wata, they are drawn into an ambiguous interdependence with others for the construction of cultural selfhoods.

\section{Viral seas}

Diffusionism perhaps has new currency in the consideration of the virality of memes. As mentioned above, culture does not work like biological genes, even if that's where the term was modeled from. Richard Dawkins (1976) conceptualised a meme as a unit of cultural information and likened it to a gene and biological information. A meme carries cultural ideas, symbols, or practices, which can be transmitted from one individual to another through writing, speech, gestures, and rituals with a mimicked theme. Through a biological understanding of cultural transmission, Dawkins posited that memes reproduce selectively and are transmitted through imitation in a manner similar to "selfish" genes, whose reproduction serves their own ends. Recent research devoted to digital memes argues against the selfish-gene metaphor, insisting that while memes spread "virally," mutating continuously and thus obfuscating the original image, they depend upon people themselves to actively transmit them, as opposed to genes which ride on their more passive hosts. In other words, memes do not operate in isolation (Burgess, 2008; Wiggins and Bowers, 2015), or with independent aims from their carriers. While memes might be understood as the language of the internet, they are not coextensive with it. They have existed as a concept long before the widespread adoption of the internet. What engenders their virality is being understood by a particular in-group. Further, it is precisely the world wide web which offers new ways to define in-groups which break free of older variables, most notably, geographic proximity.

In allowing people to reshape content to suit their own ideas, memes are new cultural productions that potentially illuminate what groups of people collectively find meaningful. What determines how widely a meme gets shared is the extent to which digital media is contingent upon participants and their relationship to the content (Shifman, 2012). Dawkins's view on the agentive quality of memes is that they continuously replicate and mutate to infect minds. This implies they have a will or even a logic of their own. An image, though utilised by people, is often thought of as having its own strong authority, particularly when it is linked to local cosmological systems, origins stories, or culturally unifying signifiers (Moore and Sanders, 2001). To be sure, a meme is not an independently willed gene; its symbiotic linkage to human culture gives the meme its ambiguous force.

There is an infectious quality involved in the virality of the transmission of internet images. If the internet has decentralised our social system, moving it into the virtual realm, it has also created new social landscapes where images are in ongoing states of modification, continuously re-inscribed with new meaning. Scholars have shown the ways in which web 2.o-based cultural diffusion depends on both word-of-mouth communication and crowdsourced content creation by online communities of engaged users (Shifman, 2012; Zhang 


\section{Braun: Catching Mama Wata}

2011; Xu, Park, \& Park, 2015). In other words, the web, much like water, is a perfect environment for shapeshifting meaning and viral spreading.

\section{Mami Wata 2.0}

Because of the fluidity of internet and digital culture, Mami Wata thrives here as she once did in her watery habitat. Further, the mutability of water as a medium that yields hybrid forms can also be extended to digital worlds where amorphous data crystalises into image. It is non-individuated procreation, occurring out in the open and always vulnerable to more influence than its originators intended. Likewise, Mami Wata's hybridity works like the multimedia possibilities of digital culture, and how content is endlessly reshaped as it is transmitted to become viral. Like many memes, it is difficult to pin down her original source. But the ability to share and receive back one's cultural products from around the globe brings anxieties about proximity and global connections, especially when they return slightly changed. In some sense, Mami Wata has always been a symbol asking us who or what we should trust.

Though often spoken about as a myth, Mami Wata and memes follow more closely the logic of rumours. Rumours, like tales, can be seen in opposition to myths. Myths attempt to create unifying narratives and naturalise social orders, while rumours and tales emerge from fringes, are unstable and destabilising, and are always adapting to continue to exert their force no matter the social conditions. Following Deleuze and Guattari in A Thousand Plateaus (1987), we see a distinction between myth and what they call tales (or, in our case, rumours). Tales participate in becoming - that is, having non-fixed, fluid states of meaning temporarily and locally constituted by encounters. Myth is pure being: a system of classification and exclusion. However, they ask, "must it not be admitted that myth as a frame of classification is quite incapable of registering these becomings, which are more like fragments of tales?" (Deleuze and Guattari, 1987: 237). This is to say that while myths will attempt and turn tales and rumours into static and disciplining knowledge, there will also be slippages, surpluses, and deformities to keep the open-ended force of rumours alive. Because in tales and rumours, "there is still room for something else, something more secret, more subterranean: the sorcerer" (1987: 237). There is a sense in which that sorcerer is our Mami Wata: a non-static figure whose existence is most felt when she is conjured in a particular context, via a certain medium, to signify specific but fleeting anxieties before swimming on. Mami Wata has always been comfortable as an urban myth/legend (another form of rumour more than a proper piece of mythology). For example, many people in Kinshasa claim to know someone (who knows someone, etc.) who has experienced some sort of encounter with Mami Wata, often taking place by the river or even a stream, and even more mysteriously, at night. In other words, people talk about it; nobody admits to outright believing it; nobody can shake the suspicion that the dangerous consequences might still befall them if they ignore it. 


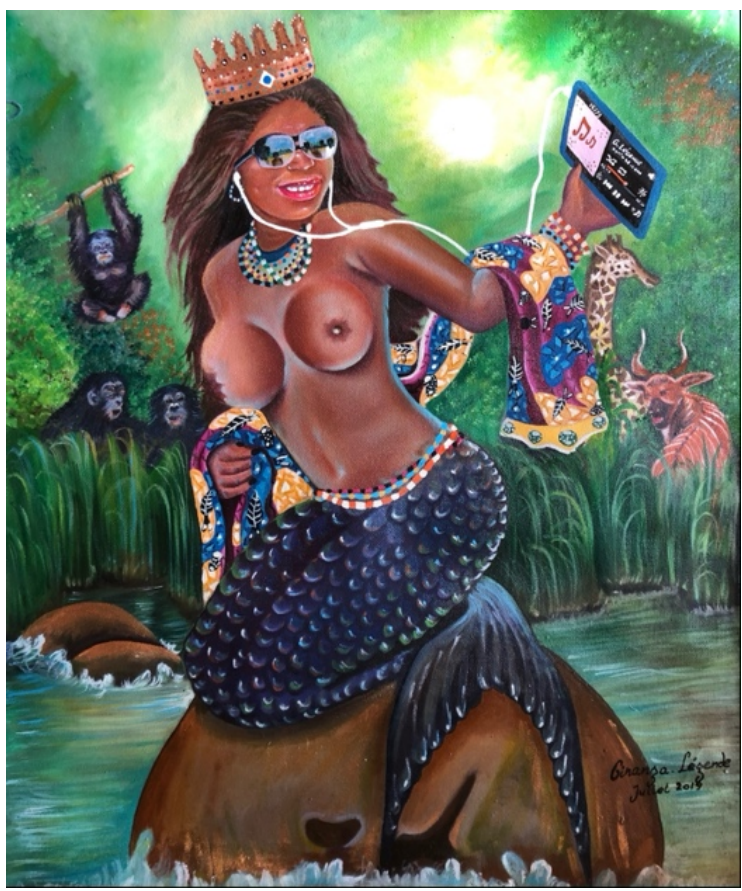

Figure 6 - Ginanga La Légende (le formateur des idoles) 2019 courtesy of Wiligama Collection.

Such urban myths flow over into the digital realm, and there combine with other urban myths from abroad. Dubious online encounters with the digital siren are increasingly being reported and circulated in stories both in real life and online. This is heightened by the advent of mobile dating apps, especially since mobile phones have become a symbol of 21st Century commodity culture worldwide. Take for instance Figure 6, by artist Ginanga La Légende depicting crowned Mami Wata set amid a wild, verdant background with an iPhone in hand. Her sunglasses serve as the mirror, itself a trope frequently used in Mami Wata paintings, reflecting the people taking the photo. Except it's not a selfie she's taking; she's listening to digital music, and it seems the artist of the painting is also credited as the recording artist on her iTunes dashboard. There is self-idolatry at work here, enforced by the name of the painting: "The Formation of Idols" ('Le Formateur des Idoles'), as well as the regent's crown she wears. It is this depiction of culture, mediated through mobile devices and global digital access, that decenters the old established gods and kings. This makes room for new, hybrid, fringe-like and destabilising processes by which we can create ourselves, and open those creations into mutually-shared acts with other unknown creatures/creators from elsewhere.

Another painting, Figure 7, Yannick Kalala Kabeya provides another meditation on the ways in which Mami Wata interacts with digital culture. Here she poses with her laptop, presumably enticing men in the virtual realm. Instead of the setting of Figure 6, this Mami Wata seems at home indoors, sitting on human-made furniture instead of a rock. All this to further attest to Mami Wata's ease of moving between realms, form the natural world to the domestic one. 


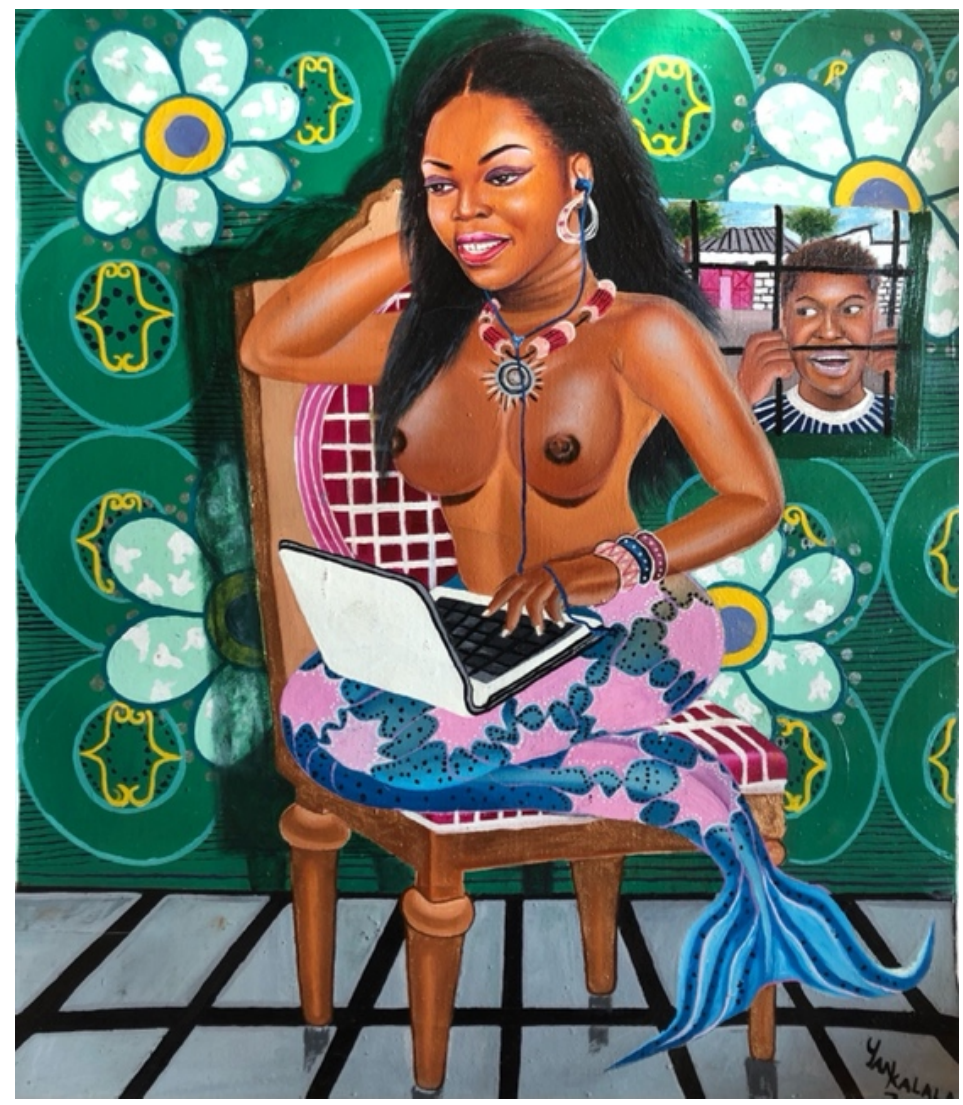

Figure 7 - Yannick Kalala Kabeya 2019 courtesy of Wiligama Collection.

There is a sense in which even mobile technology has provoked anxieties with regard to spiritual foul play. In the same way that a computer virus spreads through networks, sabotaging computers, anthropologist Julien Bonhomme's (2011) study of rumours shows similar logic. Bonhomme reports on people being killed after answering a call from an unknown telephone number. These, he argues, are some of the anxieties associated with the overlapping dynamics of social connectivity, globalisation, and local ontologies of the supernatural.

The combination of Mami Wata and media machines suggests a "mystique" linked to Congolese women, who might be perceived as central to social networks more generally, as Figures 6 and 7 both suggest. By empowering such women with globally connected electronic devices, it may hint at the ease by which local knowledge can become penetrated by outside information, or conversely, how intimate secrets can easily be "let out of the box" and shared with the world. Figure 7 especially shows this; it features a man staring in from outside, whether ogling her bare beauty or peeping her online activity. Thanks to connected mobile technology, windows to the world are everywhere.

This overlapping anxiety is perhaps consolidated in the mobile as one screen features news, entertainment, social media, gossip, rumours and propaganda simultaneously. The virality 
of digital content also threatens to leap into the material world. For example, in Kinshasa, downloading or even watching an "infected" video with an alleged Mami Wata is something many people are apprehensive about. In many ways, memes and digital content function like rumours in their person-to-person transmission. "Very often the term "viral video' is used to refer simply to those videos which are viewed by a large number of people, generally as a result of knowledge about the video being spread rapidly through the internet population via word-of-mouth" (Burgess, 2008: 52). But nonetheless, its spreading and infectious character can be interpreted as having the dangerous effects of a real virus (digital or otherwise). The origins of digital content are often unknown, endless shapeshifting and mass virality can sometimes break down confidence in what is real and what is not. This causes anxieties that further blur the line between digital virality and material infection. And above all, viral videos are increasingly important in the construction and circulation of rumour in Kinshasa, as this next example shows.

\section{Mami Wata captured?}

Let us now consider an older Mami Wata rumour that circulated in the city of Kinshasa in 2012 in the form of a viral video. While this story has been unpacked in greater detail elsewhere (Brau, 2015), it is relevant to discussions about the increased digitisation of Mami Wata, especially with regards to memes as an emergent visual expression. The video showed a grotesque sea-creature with a gnarled and shriveled body in a large room, surrounded and prodded by curious men. The style of the video was as if taken on a mobile phone, the user struggling through the crowd to shoot glimpses of the spectacle. The video was presented as news, with journalists describing and commenting on Mami Wata's appearance. According to the story, Mami Wata had been apprehended by Chinese engineers who were installing underwater fiber optic internet cables in the Congo River. On the evening of 30 April 2012, during a popular roundtable discussion on the national television station RTNC, several panelists analyzed the Mami Wata viral video and encouraged viewers to call in and offer commentary (it should be mentioned that not everyone believed that this was even remotely real).

Beyond Mami Wata's presence being mediated by the internet, she is presented in the video as official news and thus not simply an artistic representation or meme content. The fact that the video was featured on several national television programs lent it a certain level of legitimacy. This shows us again how when she is presented through a new medium (the news), it heightens the ambiguous dual nature between fantastic creature and actual being, causing uneasy feelings of uncertainty.

There were material effects of this video rumour that went beyond its viral-sharing qualities. For some weeks after the video first surfaced, people were reportedly wary of daily activities that involved going near the river, like washing clothing. Disruptions in the rhythm of daily life are one consequence of such ambiguous spectacles of reality. This supposed dismissal of the supernatural necessarily betrays an enduring superstitious nervousness - that not taking it seriously is a defense against its potential power if one did. Viral content has material infectious qualities. And true to the ideas of diffusionist theory, this video has surfaced to be refashioned and remixed by other cultures. For example, in Indonesia, the creature in the video was identified as the blood-drinking Jenglot, another folkloric figure. Jenglot is also sometimes seen with a serpent's tail, but other non-aquatic 


\section{Braun: Catching Mama Wata}

versions have shriveled legs. ${ }^{2}$ With viral transmission, she adapts not only in form but in name and claim. One notes that breaking with tradition, here Mami Mata is far from beautiful. It is almost disturbing, scary (Figures 9 and 10). It's the beautiful female turned inside out to reveal her ugly intentions. It's also the mirror-image anxiety of the fear in the encounter of the other.
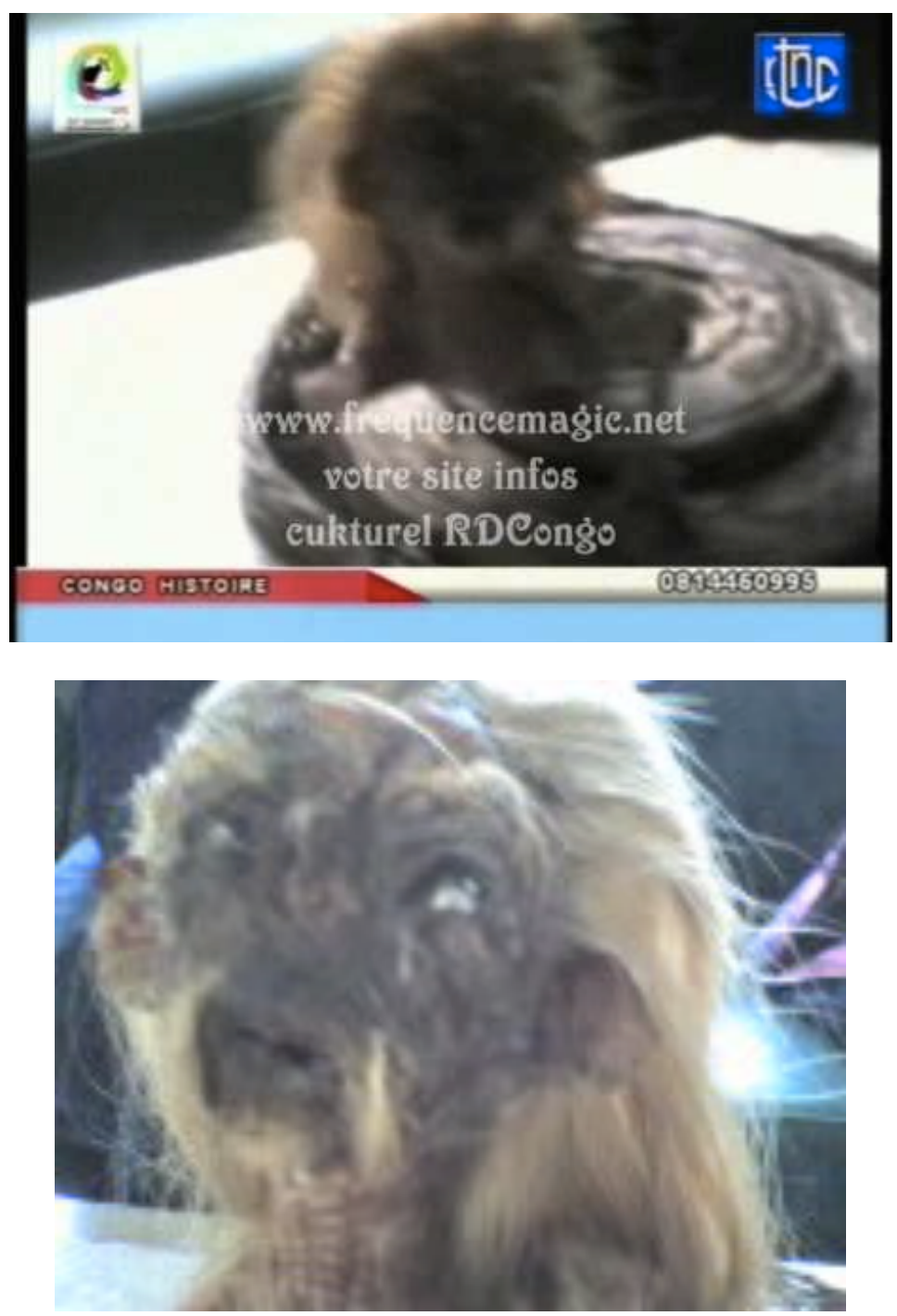

Figures 9 and 10 - Stills from the RTNC news report (online at: https://www.youtube.com/watch?v=h8oTchh15_E)

\footnotetext{
${ }^{2}$ For the same video circulating in Indonesia see: https://www.youtube.com/watch?v=Hof_jjVWgzM
} 


\section{Braun: Catching Mama Wata}

The fact that she was caught and hauled in for inspection, perhaps serves to demystify her force and turn her into something closer to an animal, more sea creature than hybrid siren. Does this video externalise the projection that the Chinese, in their push for modernisation, need to render impotent the Kinshasa's symbols of the past? Further, because Mami Wata, so elusive, never before leaving behind any material proof of her body, was rumoured to be discovered by the Chinese has confirmed for many people just how powerful the Chinese are. Mami Wata could have been protecting the river from the very fiber optic coils that promise to bring the world onto the screens of every African. Her disfigurement can also be read as a symbol of mother nature herself after suffering the ravages of industrial resource extraction. These anxieties are possibly related to the infrastructure the Chinese are building all over the African content, and with it, the threats of unbridled global capitalism. In her monstrous form, perpetuated through the virality of digital memes, we are presented again with an anxiety about proximity, encounter, otherness, and change.

The ways Mami Wata and digital culture circulate demonstrate how the internet is a vehicle for encounters with otherness. Further, both expressions are inter-participatory; their meanings coexist in constant evolution. Parallels can also be made between the virality of memes and Mami Wata's memetic force, in that they are mutable and shapeshifting, both inspiring myths and coalesce into rumours and back again.

\section{Unknown waters}

Whereas once Mami Wata was a threat emanating from the water, with the case of the Chinese engineers, she might also be seen as its protector. Her dual nature of dangerous siren and mother protector flows again to the surface. This shift from lure to protectress is made possible by Mami Wata's fluid nature and how her memetic force thrives in digital culture. Like moving on water, one cannot predict which path her semantic force will follow. As rumours and memes, her survival through time and across space depends on the active participatory transmission by users, in-groups and disparately connected people, as well as endless adaptability in socio-historic contexts. Images circulating on the internet, particularly memes, like rumours, are dependent on participatory processes in not only the shaping and reshaping of their content, for example, visual and narrative, but also in keeping them alive within the collective conscious.

Permanence is death. Mutability is life. And while her presence will always carry with it anxieties-from male anxiety over the female, to the modern anxieties of global culture and digital encounter-her endurance can also serve as the comforting guide to navigate the dark waters of the unknown.

\section{BIBLIOGRAPHY:}

Biaya, T.K (1996) 'La culture urbaine dans les arts populaires d'Afrique: analyse de l'ambiance zairoise', Canadian Journal of African Studies / Revue Canadienne des Etudes Africaines n3o: 345-370

Boas, F (1904) 'The history of anthropology', Science n2o: 513-524 


\section{Braun: Catching Mama Wata}

Bonhomme, J (2011) 'Les numéros de téléphone portable qui tuent: epidemiologie culturelle d'une rumeur transnationale', Tracés n21 (Contagion/Contamination): 125-150

Burgess, J 2(0o8) 'All you chocolate rain are belong to us? Viral videos, youtube and the dynamics of participatory culture', in Loovink, G and Niderer, S (eds) Video Vortex Reader: Responses to Youtube, Amsterdam: Institute of Network Cultures: 101-109

Braun, L (2015) 'Cyber siren: what mami wata reveals about popular culture and the Chinese presence in Kinshasa', Canadian Journal of African Studies v45 n2: 301-318

Braun, L (2020) 'Infectious images: an interdisciplinary approach to understanding viral internet content in the Democratic Republic of Congo', Critical Arts v34 n4: 103-116

Dawkins, R (1976) The selfish gene, Oxford: Oxford University Press

Deleuze, G and Guattari, F (1987) A thousand plateaus: capitalism and schizophrenia, Minneapolis: University of Minnesota Press

Drewal, H.J (1988) 'Performing the other: Mami wata worship in Africa', The Drama Rewview v32 n2: 160-185

Drewal, H.J (2008) 'Mami wata arts for water spirits in Africa and Its diasporas', African Arts v41 n2: 6o-83

Drewal, H.J (2013) 'Local transformations, global inspirations: the visual histories and cultures of Mami Wata arts in Africa', in Salami, G and Blackmun, M (eds) A companion to modern African art, Hoboken: Wiley-Blackwell: 23-50

Fabian, J (1996) Remembering the present: painting and popular history in Zaire, Berkeley: The University of California Press

Glissant, E (1997) [1928], Poetics of relation, Michigan: University of Michigan Press

Gondola, C.D (1997) 'Popular music, urban society, and changing gender relations in Kinshasa, Zaire', in Grosz-Ngatem, M and Kokole, O (eds) Gendered Encounters: Challenging Cultural Boundaries and Social Hierarchies in Africa, New York: Routledge: 6583

Jewsiewicki, B (2003) Mami Wata: pa peinture urbaine au Congo, Paris: Gallimard

Kroeber, A.L (1923) Anthropology, New York: Harcourt, Brace

Moore, $\mathrm{H}$ and Sanders, $\mathrm{T}$ (eds) (2001) Magical interpretations, material realities: modernity, witchcraft, and the occult in Postcolonial Africa, London: Routledge

Murdock, G.P (1940) 'The cross-cultural survey', American Sociological Review n5:361-70

Touya, L (2004) Mami Wata la Sirène et les peintres populaires de Kinshasa, Paris: Harmattan 


\section{Braun: Catching Mama Wata}

Wiggins, B.E and Bowers, B.G (2015) 'Memes as genre: A structurational analysis of the memescape', New Media \& Society v17 nı: 1886-1906

Shifman, L (2012) 'An anatomy of a Youtube meme', New Media E Society v14 n2: 187-203

Xu, W.W, Park, J.W and Park, H.W (2016) 'Networked cultural diffusion and creation on YouTube: An analysis of YouTube memes', Journal of Broadcasting E Electronic Media v6o n1: 104-122

Zhang, N (2011) 'The role of Web 2.0 applications on niche culture diffusion: an empirical study on the influence of online forums on fans of rock music', Online Information Review n35: $734-746$

Yoka, L.M (1999) Kinshasa, signes de vie, Paris: L'Harmattan 